\title{
Left ventricular ejection fraction and left atrium diameter related to new-onset atrial fibrillation following acute myocardial infarction: a systematic review and meta-analysis
}

\author{
Rui-Xiang Zeng ${ }^{1, *}$, Mao-Sheng Chen ${ }^{1, *}$, Bao-Tao Lian ${ }^{1}$, Peng-Da Liao ${ }^{1}$ and Min-Zhou \\ Zhang ${ }^{1}$ \\ ${ }^{1}$ Division of Chest Pain Center, Guangdong Provincial Hospital of Chinese Medicine, The 2nd Clinical College of Guangzhou \\ University of Chinese Medicine, Guangzhou, 510120, P.R. China \\ *These authors contributed equally to this work
}

Correspondence to: Min-Zhou Zhang, email: minzhouzhang@aliyun.com

Keywords: atrial fibrillation, left ventricular ejection fraction, left atrium diameter, acute myocardial infarction

Received: April 25, $2017 \quad$ Accepted: August 23, $2017 \quad$ Published: September 11, 2017

Copyright: Zeng et al. This is an open-access article distributed under the terms of the Creative Commons Attribution License 3.0 (CC BY 3.0), which permits unrestricted use, distribution, and reproduction in any medium, provided the original author and source are credited.

\section{ABSTRACT}

Background: New-onset atrial fibrillation (NOAF) occurs frequently in patients with acute myocardial infarction (AMI), and is associated with increased subsequent cardiovascular mortality. However, only a few studies directly evaluated the relationship of left ventricular ejection fraction (LVEF) or left atrium diameter (LAD) and NOAF following AMI.

Materials and Methods: MEDLINE ${ }^{\circledR}$, EMBASE$^{\circledR}$ and the Cochrane Library were carried out to find studies until January 2017. Pooled mean difference (MD) and $95 \%$ confidence interval (CI) were calculated to evaluate the value of LVEF and LAD in the prediction of NOAF after AMI. We performed sensitivity analyses to explore the potential sources of heterogeneity. Statistical analyses were carried out using the Revman 5.3.

Result: We included 10 qualifying studies comprising a total of 708 patients with NOAF and 6785 controls. Overall, decreased LVEF and increased LAD levels had a significant positive association with NOAF in patients with AMI. The MD in the LVEF levels between the patients with and those without NOAF was -4.91 units $(95 \% \mathrm{Cl}$ : -5.70 to -4.12$)$, test for overall effect $z$-score $=12.18\left(p<0.00001, I^{2}=35 \%\right)$. Moreover, in a subgroup analysis, the MD for LAD and NOAF was 2.55 units $(95 \% \mathrm{Cl}$ : 1.91 to 3.19$)$, test for overall effect $z$-score $=7.80\left(p<0.00001, I^{2}=57 \%\right)$.

Conclusions: Our meta-analysis demonstrated that both decreased LVEF and increased LAD levels were associated with greater risk of NOAF following AMI.

\section{INTRODUCTION}

Atrial fibrillation (AF) occurs commonly in hospitalized patients with acute myocardial infarction (AMI), with a reported incidence between $2 \%$ and $20 \%$ [1], and is closely associated with prolonged hospitalization, increased subsequent cardiovascular mortality in AMI patients [2-6]. The development of AF in the AMI setting is multiple factors, including older age, systemic inflammation, heart failure, acute ischemia, elevated left ventricular (LV) end-diastolic pressure, left atrial (LA) enlargement or infarction [7]. As well known, left ventricular ejection fraction (LVEF) serves as a significant prognostic marker of cardiac function, and left atrium diameter (LAD) responses to whether left atrial enlargement or not, both of those abnormalities are considered as a risk predictor for cardiovascular disease. However, to our knowledge, only a few studies directly evaluated the associations between LVEF or LAD and newonset AF (NOAF) in patients with AMI. So we conducted this comprehensive meta-analysis to explore the impact of LVEF on NOAF following AMI by collecting data for previously published studies. Furthermore, the relationship of LAD and NOAF was assessed by a subgroup analysis. 


\section{MATERIALS AND METHODS}

\section{Literature search}

Our study strictly complies with the guidelines of the meta-analysis of observational studies in epidemiology group (MOOSE) [8]. A comprehensive systematic search of MEDLINE $^{\circledR}$, EMBASE $^{\circledR}$ and the Cochrane Library was carried out to find relevant studies until January 2017. Searches combined free-text and MeSH terms relating to "left ventricular ejection fraction" or "LVEF," "atrial fibrillation" and "myocardial infarction" or "myocardial infarct". Reference lists from the identified articles were manually examined for relevant new articles. Abstracts, unpublished reports, and non-English language articles were not included.

\section{Inclusion and exclusion criteria}

The inclusion criteria were as follows: 1) the study had the baseline LVEF levels data based on with and without NOAF after AMI; and 2) the study used NOAF rates as an outcome. The exclusion criteria were: 1) history of AF and did not focus on AMI; 2) lacked of preprocedural LVEF levels; 3) Abstracts without the full text.

\section{Identification of studies}

We restricted our search to studies published in English. Abstracts and titles of related articles were initially scanned by a reviewer. Potentially relevant articles were then considered by at least 2 independent reviewers. Disagreements were resolved by discussion or upon consensus from a $3 \mathrm{rd}$ or 4 th reviewer. Two reviewers agreed on the inclusionary or exclusionary status of $90 \%$ of the reviewed studies. Full texts of the selected articles were then screened by both authors for inclusion in the review. All disagreements were resolved by consensus.

\section{Quality assessment and data extraction}

Quality assessments were evaluated with the Newcastle-Ottawa Scale (NOS) list for nonrandomized studies. Each study was assessed in three aspects using this "star system": the selection of the study groups; the comparability of the groups; and the ascertainment of the outcome of interest (Supplementary Tables 1 and 2).

Two blinded reviewers independently used a standardized data-extraction form to determine appropriately to extract data. We extracted data included the lead author's last name, the publication year, and the origin of the studied population; the study design; the characteristics of the studied population (sample size, age, sex, time of AF detection, and withdrawals and dropouts of patients); endpoint evaluations (definitions of NOAF and methods of AF detection); rates of NOAF; and means and SDs of LVEF in each group. Disagreements were resolved by consensus from another reviewer.

\section{Statistical analysis}

The association strength between LVEF or LAD and NOAF was measured by the mean difference (MD) and $95 \%$ confidence interval $[\mathrm{CI})$. The significance of pooled MD was tested by $z$-test $(P<0.05$ was considered significant). Heterogeneity was evaluated with Cochran's $\mathrm{Q}$ statistic and quality by $\mathrm{I}^{2}$ statistic. We premeditated that mild heterogeneity might be less than 30 percent of the variability in point estimates and the values of $\mathrm{I}^{2}$ exceeding $50 \%$ might express as significant heterogeneity [9], so we used the random-effects model for our study and between study variance, otherwise, with a fixed-effects model. To explore sources of heterogeneity, we performed several sensitivity analyses. Publication bias was also evaluated by inspecting funnel plots. All analyses were conducted with the use of Review Manager, version 5.3 (Revman, The Cochrane Collaboration; Oxford, UK).

\section{RESULTS}

\section{Search results}

The search yielded 546 research reports, of which 49 were excluded for having the same title or authors; 454 were excluded because they were laboratory studies, animal studies, review articles, or irrelevance to the current analysis. Of the remaining 33 studies, 21 studies did not assess the NOAF or AMI. 8 studies researched segmental LVEF levels and lacked of concrete LVEF data. 2 studies included the history of AF. One study just published by abstract. One study included patients after cardiac surgery. The foregoing studies were all excluded, and 10 observational studies [10-19] were finally included in our meta-analysis (Figure 1). As a result, 7493 patients were involved in our analysis: 708 patients in $\mathrm{AF}$ group and 6785 patients in without AF group.

\section{Baseline characteristics and quality assessment}

The NOS for assessing the quality of the 10 studies is shown in Table 1 and the scores ranged from 6-7. Table 2 presents the characteristics of each study. The average age of patients in the included studies ranged from 58 to 74 years and the rate of NOAF ranged from $7.44 \%$ to $20.7 \%$.

\section{Quantitative data synthesis and heterogeneity analysis}

Overall, decreased baseline LVEF levels had a significant positive association with NOAF in patients with AMI. The MD in the LVEF levels between the patients with and those without NOAF was -4.91 units ( $95 \% \mathrm{Cl}:-5.70$ to -4.12$)$, test for overall effect z-score 
$=12.18\left(p<0.00001, \mathrm{I}^{2}=35 \%\right)$ (Figure 2$)$. However, an asymmetric funnel plot showed the possible existence of publication bias (Figure 3). Because of small sample size, we could not explain the exact cause of heterogeneity in our meta-analysis.

Moreover, The MD in a subgroup analysis for LAD levels between the patients with, and those without NOAF was 1.34 units $(95 \% \mathrm{Cl}: 1.04$ to 1.64$)$, test for overall effect $\mathrm{z}$-score $=8.75\left(p<0.00001, \mathrm{I}^{2}=79 \%\right)$ (Figure 4). The heterogeneity test showed that there were significant differences between individual studies $\left(p<0.00001 ; \mathrm{I}^{2}=\right.$ $79 \%$ ). We subsequently performed sensitivity analyses in order to identify the origin of this heterogeneity [20]. As shown in Figure 5, after excluding the studies by Aronson D et al. [19] the heterogeneity test showed less effects on the results $\left(p<0.00001, \mathrm{I}^{2}=57 \%\right)$, whereas the $\mathrm{MD}$ in the LAD levels between the patients with and without NOAF was 2.55 units ( $95 \% \mathrm{Cl}: 1.91$ to 3.19), test for overall effect z-score $=7.80(p<0.00001)$. As known, the study by
Aronson D et al. [19] had a longer follow-up period of 6 months, which was different from the remaining 6 studies, and this might be a possible source of heterogeneity.

\section{DISCUSSION}

Interestingly, our meta-analysis demonstrated that lower LVEF levels were associated with NOAF occurrence after AMI. Furthermore, in a subgroup analysis, we also found that increased LAD levels related to greater risk of NOAF following AMI, although there was significant heterogeneity. Nonetheless, sensitivity analyses indicated that differences in follow-up period might account for the heterogeneity. Thus, present study might provide insights into mechanisms and lead to greater understanding of the risk factors for NOAF after AMI.

As well known, current evidence regarding the associations between NOAF and in-hospital or longterm outcomes in AMI patients is convincing. These

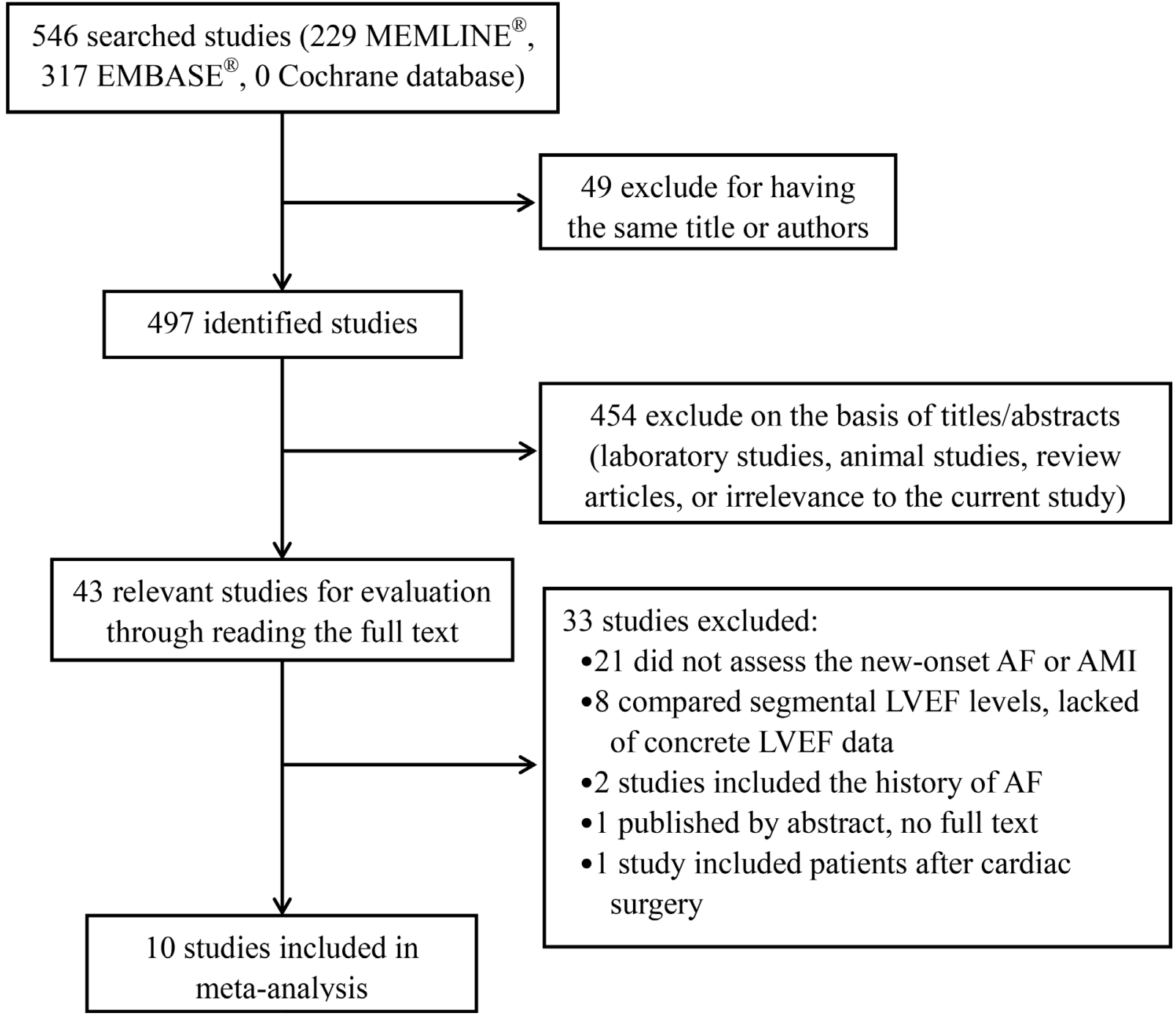

Figure 1: Flow diagram of the trial-selection process. AF = atrial fibrillation; AMI = acute myocardial infarction; LVEF $=1$ left ventricular ejection fraction. 
Table 1: Evaluation of the quality of the 10 included studies by using the Newcastle-Ottawa Scale ${ }^{\#}$

\begin{tabular}{|c|c|c|c|c|c|c|c|c|c|c|}
\hline \multirow[t]{2}{*}{ Factor } & \multirow[t]{2}{*}{ Study type } & \multicolumn{4}{|c|}{ Selection } & \multirow[t]{2}{*}{ Comparability } & \multicolumn{3}{|c|}{$\begin{array}{c}\text { Exposure or } \\
\text { outcome }\end{array}$} & \multirow{2}{*}{$\begin{array}{l}\text { No. of } \\
\text { star }\end{array}$} \\
\hline & & 1 & 2 & 3 & 4 & & 1 & 2 & 3 & \\
\hline Cicek 2003 & Case-Control Study & $*$ & $*$ & $*$ & * & $*$ & $*$ & $*$ & & 7 \\
\hline Aronson 2007 & Cohort Study & $*$ & $*$ & $*$ & $*$ & $*$ & $*$ & $*$ & & 7 \\
\hline Gedikli 2008 & Case-Control Study & $*$ & $*$ & $*$ & $*$ & $*$ & $*$ & $*$ & & 7 \\
\hline Bahouth 2009 & Cohort Study & $*$ & * & $*$ & * & $*$ & $*$ & $*$ & & 7 \\
\hline Hwang 2011 & Case-Control Study & $*$ & $*$ & $*$ & $*$ & $*$ & $*$ & $*$ & & 7 \\
\hline Aronson 2011 & Cohort Study & $*$ & $*$ & $*$ & * & $*$ & $*$ & $*$ & & 7 \\
\hline Yoshizaki 2012 & Case-Control Study & $*$ & $*$ & $*$ & $*$ & $*$ & $*$ & $*$ & & 7 \\
\hline Dorje 2013 & Case-Control Study & $*$ & $*$ & $*$ & $*$ & $*$ & $*$ & $*$ & & 7 \\
\hline Guenancia 2014 & Case-Control Study & $*$ & $*$ & $*$ & & $*$ & $*$ & $*$ & & 6 \\
\hline Zhang 2014 & Case-Control Study & * & * & * & * & * & & * & & 6 \\
\hline
\end{tabular}

"The Newcastle-Ottawa Scale criteria are listed in supplementary files.

Table 2: Characteristics of the 10 studies included in the meta-analysis

\begin{tabular}{|c|c|c|c|c|c|c|c|c|c|c|}
\hline Factor & Year & $\begin{array}{c}\text { Study } \\
\text { population }\end{array}$ & $\begin{array}{l}\text { Patients, } \\
\text { n }\end{array}$ & $\underset{\mathbf{n}}{\text { Male, }}$ & $\begin{array}{c}\text { Mean } \\
\text { Age, } \\
\text { yrs }\end{array}$ & $\begin{array}{c}\text { New- } \\
\text { onset AF } \\
\text { rate, } \%\end{array}$ & $\begin{array}{c}\text { Time of AF } \\
\text { detection }\end{array}$ & $\begin{array}{c}\text { Timing } \\
\text { of LVEF } \\
\text { determination }\end{array}$ & Methods of AF detection & $\begin{array}{c}\text { Method of } \\
\text { revascularization }\end{array}$ \\
\hline $\begin{array}{l}\text { Cicek D, } \\
\text { et al. }\end{array}$ & 2003 & Turkey & 100 & 77 & 59 & $19 \%$ & $\begin{array}{c}\text { During } \\
\text { hospitalization }\end{array}$ & N/A & $\begin{array}{l}\text { ECG was monitored } \\
\text { continuously }\end{array}$ & Thrombolytic (69\%) \\
\hline $\begin{array}{l}\text { Aronson D, } \\
\text { et al. }\end{array}$ & 2007 & Israel & 1209 & 936 & 62 & $11.3 \%$ & $\begin{array}{c}\text { During } \\
\text { the index } \\
\text { hospitalization }\end{array}$ & $\begin{array}{c}\text { Pre- } \\
\text { interventional }\end{array}$ & Telemetry strips and ECGs & N/A \\
\hline $\begin{array}{l}\text { Gedikli O, } \\
\text { et al. }\end{array}$ & 2008 & Turkey & 92 & 67 & 58 & $20.7 \%$ & $\begin{array}{l}\text { During the first } \\
7 \mathrm{~d} \text { after AMI }\end{array}$ & $\mathrm{N} / \mathrm{A}$ & $\begin{array}{l}\text { ECG was monitored } \\
\text { continuously }\end{array}$ & $\mathrm{N} / \mathrm{A}$ \\
\hline $\begin{array}{l}\text { Bahouth F, } \\
\text { et al. }\end{array}$ & 2009 & Israel & 1920 & 1505 & 64 & $8.4 \%$ & $\begin{array}{l}\text { At admission or } \\
\text { later during the } \\
\text { hospital stay }\end{array}$ & $\begin{array}{l}\text { A median of } \\
2 \text { days from } \\
\text { admission }\end{array}$ & Telemetry strips and ECGs & N/A \\
\hline $\begin{array}{l}\text { Hwang HJ, } \\
\text { et al. }\end{array}$ & 2011 & $\begin{array}{l}\text { South } \\
\text { Korea }\end{array}$ & 401 & 294 & 61 & $8.2 \%$ & $\begin{array}{l}\text { Within } 24 \mathrm{~h} \\
\text { after AMI }\end{array}$ & $\begin{array}{c}\text { Pre- } \\
\text { interventional }\end{array}$ & Telemetry strips and ECGs & $\begin{array}{l}\text { PTCA, CABG or medical } \\
\text { treatment }\end{array}$ \\
\hline $\begin{array}{l}\text { Aronson D, } \\
\text { et al. }\end{array}$ & 2011 & Israel & 1169 & 817 & 64 & $9.4 \%$ & $\begin{array}{l}\text { During a } \\
\text { follow-up } \\
\text { period of } 6 \\
\text { months. }\end{array}$ & $\begin{array}{l}\text { A median of } \\
2 \text { days from } \\
\text { admission }\end{array}$ & Telemetry strips and ECGs & $\mathrm{N} / \mathrm{A}$ \\
\hline $\begin{array}{l}\text { Yoshizaki T, } \\
\text { et al. }\end{array}$ & 2012 & Japan & 176 & 152 & 74 & $13.6 \%$ & $\begin{array}{c}\text { During } \\
\text { hospitalization }\end{array}$ & $\begin{array}{l}\text { On day 5-7 of } \\
\text { admission }\end{array}$ & $\begin{array}{l}\text { ECG was monitored } \\
\text { continuously }\end{array}$ & N/A \\
\hline $\begin{array}{l}\text { Dorje } T \text {, et } \\
\text { al. }\end{array}$ & 2013 & China & 268 & 224 & 64 & $13.4 \%$ & $\begin{array}{l}\text { During the AMI } \\
\text { hospitalization }\end{array}$ & $\begin{array}{c}\text { Pre- } \\
\text { interventional }\end{array}$ & Telemetry strips and ECGs & N/A \\
\hline $\begin{array}{l}\text { Guenancia } \\
\text { C, et al. }\end{array}$ & 2014 & France & 1123 & 779 & 79 & $8.1 \%$ & $\begin{array}{l}\text { During the AMI } \\
\text { hospitalization }\end{array}$ & On admission & Telemetry strips and ECGs & $\begin{array}{l}\text { PCI }(69 \%) \\
\text { Other }(31 \%)\end{array}$ \\
\hline $\begin{array}{l}\text { Zhang } \\
\text { et al. }\end{array}$ & 2014 & China & 1035 & 693 & 65 & $7.44 \%$ & $\begin{array}{l}\text { During the AMI } \\
\text { hospitalization }\end{array}$ & $\begin{array}{c}\text { Pre- } \\
\text { interventional }\end{array}$ & $\begin{array}{l}\text { ECG was monitored } \\
\text { continuously }\end{array}$ & $\begin{array}{c}\text { PCI }(23.38 \%) \\
\text { Thrombolysis }(1.30 \%)\end{array}$ \\
\hline
\end{tabular}

outcomes include the length of hospital stay, heart failure, stroke, recurrent myocardial ischemia, major bleeding and increased mortality [5, 21-25]. Therefore, prediction of NOAF following hospitalization for AMI may reduce clinical adverse events [26]. In the setting of AMI, previous studies have demonstrated a number of risk factors for NOAF in AMI patients, such as old age, female gender, obesity, history of hypertension, history of stroke, higher Killip class or heart failure, hypotension, higher heart rate, higher CHADS2 score, increased peak creatinine kinase, $\mathrm{C}$-reactive protein and $\mathrm{N}$-terminal probrain natriuretic peptide levels $[5,6,13,16,21,23-25$, 
27, 28]. To our knowledge, this is the first meta-analysis directly evaluating the impact of LVEF and LAD on NOAF in patients with AMI.

Even though the exact mechanism for LVEF or LAD in AMI patients with NOAF was still unclear, several previous relevantly studies have contributed evidence to investigate it and provided potential responsible mechanisms. Aronson and colleagues reported that both LVEF and LAD were independently associated with NOAF, suggesting that increased LV filling pressures may contribute to the development of AF after AMI [19]. Numbers of studies have reported multitudinous pathologic mechanisms of AF following AMI, which could include abrupt changes such as increased LV filling

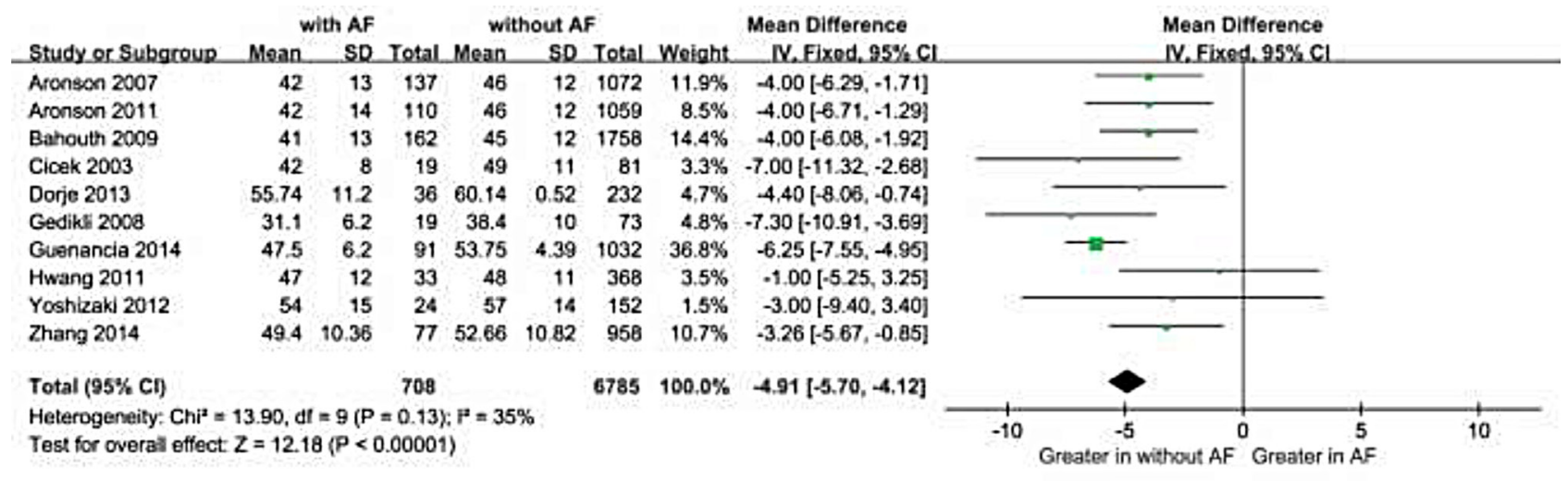

Figure 2: Comparison of LVEF levels between AF and without AF groups in the 10 included studies. $\mathrm{CI}=$ confidence interval; $\mathrm{AF}=$ atrial fibrillation; $\mathrm{LVEF}=$ left ventricular ejection fraction.

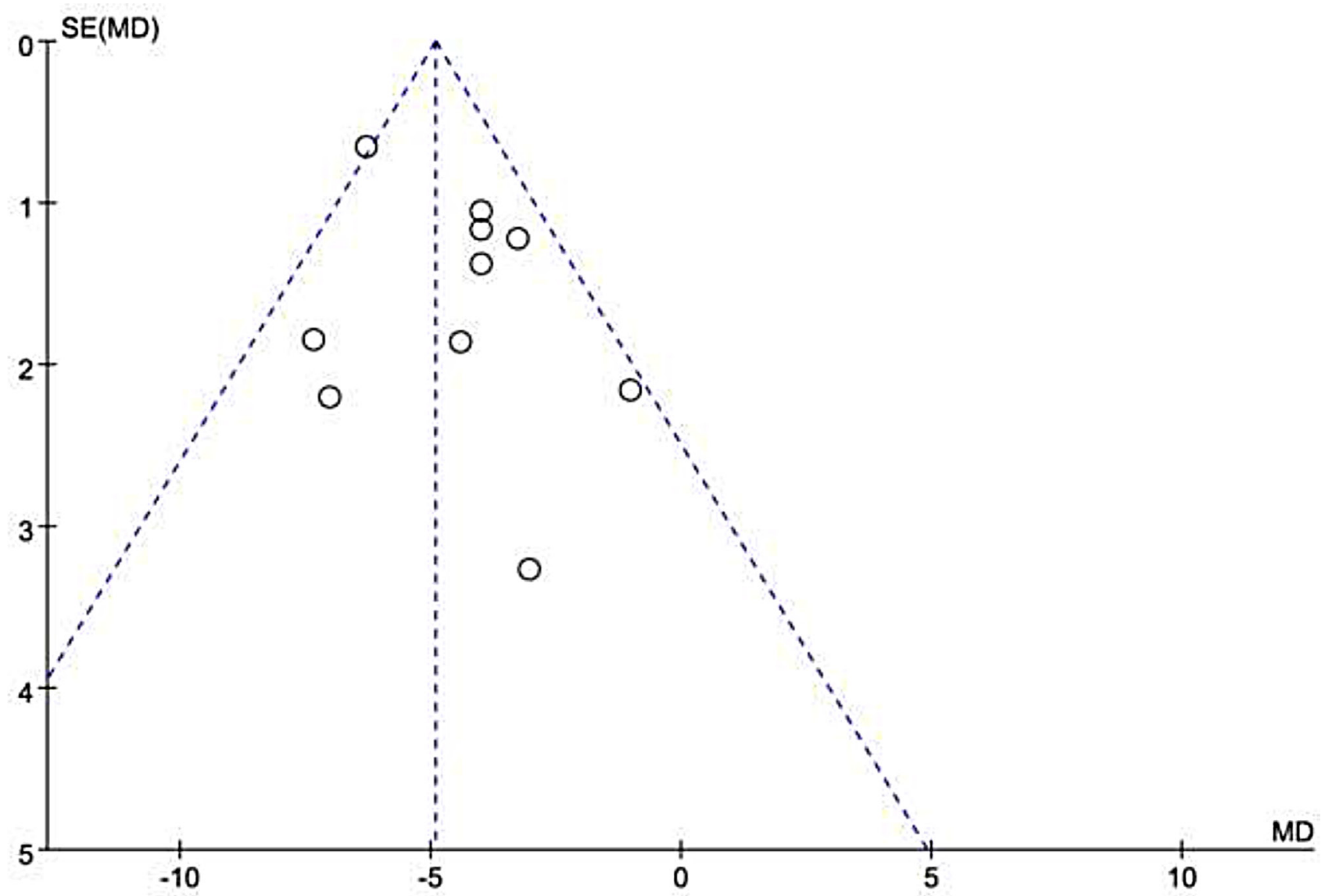

Figure 3: Funnel plot of the 10 included studies. $\mathrm{SE}=$ standard error; $\mathrm{MD}=$ mean difference. 
pressure, deterioration of LV systolic functions, or direct ischemic insult of the atria $[11,22,23,29-32]$. AMI often results in change LV filling dynamics, which may lead to advanced diastolic dysfunction. Subsequently, diastolic dysfunction may produce increased LA pressure and initiate LA remodeling, promoting the progression to $\mathrm{AF}[5,7,19]$. In addition, experimental and clinical researches have demonstrated that increasing atrial pressure and/or causing acute atrial dilatation may act an important part in the development of AF in the AMI [5-7, 18, 29, 33]. Hence, it was not difficult to understand that left atrial enlargement that assessed by LAD was major predisposing factors for the development of $\mathrm{AF}$ [34-36]. Overall, all of above might indicate the potential mechanisms for the result of the present meta-analysis.

From the conclusion of this study, we could deduce that decreased LVEF and increased LAD levels might be associated with worse clinical prognosis in patient with NOAF following AMI. Early identification of patients with AMI who are at risk of AF attack is of particular importance. Hence, NOAF should be close monitoring for avoiding hemodynamic depression. Management of AF in patients with AMI should follow guideline recommendations [37-39]. It has been well established that oral anticoagulation is a proven therapy for stroke prevention in AF patients with high thromboembolic risk [21]. However, there is insufficient evidence to support prophylactic anticoagulant therapy for AMI patients with high risk of AF. Further studies specific to AF prevention in the patient with AMI are needed.

Our meta-analysis may provide worthy and reliable information regarding the relationships between LVEF, $\mathrm{LAD}$, and NOAF in patients with AMI. However, there are still some potential limitations to this meta-analysis. First, the definitions of NOAF and methods of AF detection were not accordant, and some information on the timing of LVEF determination and the method of revascularization was not applicable, which might be subject to the source of potential bias. Second, most of the included studies did not directly research the impact of LVEF and/or LAD on NOAF after AMI, some potential confounders might have not entirely eliminated. Third, our analysis was based on observational studies, and the numbers of studies and patients were rather limited. Finally, the conclusions of the absence of publication bias were not always reliable. Therefore, the results of our analysis should be interpreted cautiously, and future investigations are needed to clarify the mechanisms of NOAF further.

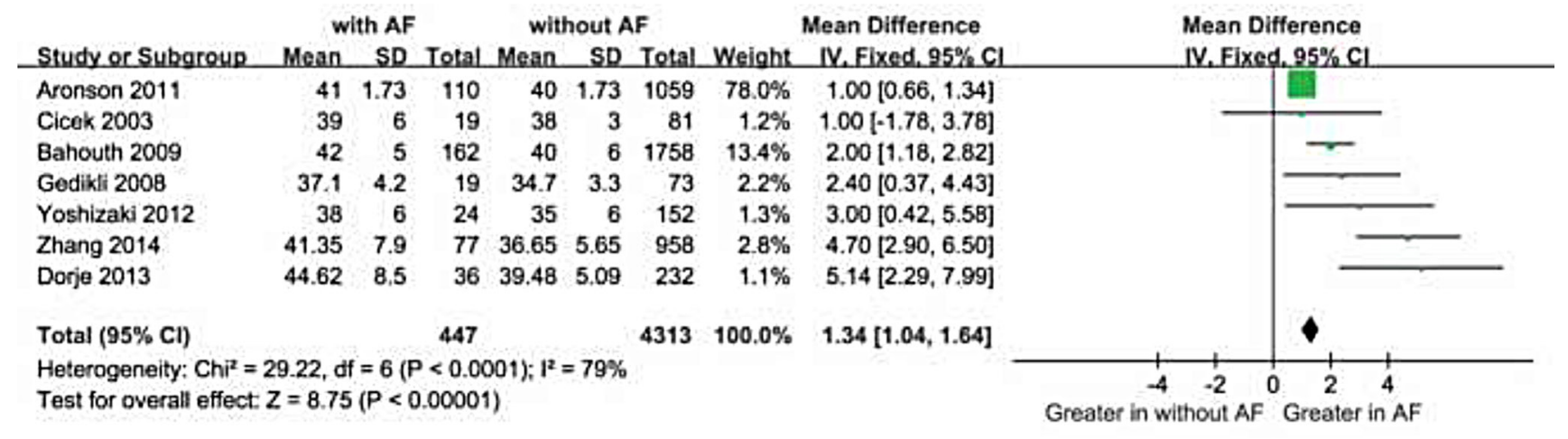

Figure 4: Comparison of LAD levels between AF and without groups in the 7 included studies. CI = confidence interval; $\mathrm{AF}=$ atrial fibrillation; $\mathrm{LAD}=$ left atrium diameter.

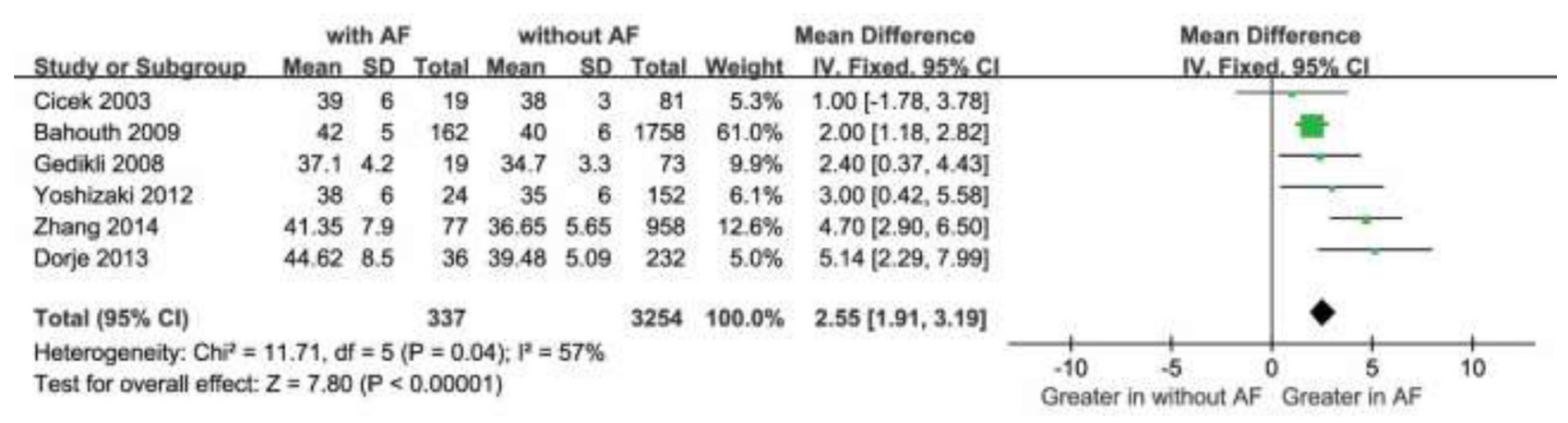

Figure 5: Comparison of LAD levels between AF and without groups in the remaining 6 included studies. $\mathrm{CI}=$ confidence interval; $\mathrm{AF}=$ atrial fibrillation; $\mathrm{LAD}=$ left atrium diameter. 


\section{CONCLUSIONS}

In conclusion, our meta-analysis demonstrated that both decreased LVEF and increased LAD levels might be associated with greater risk of NOAF following AMI, which contributing compelling evidence that LVEF and LAD may be a useful marker in predicting NOAF in AMI patients.

\section{CONFLICTS OF INTEREST}

The authors have no conflicts of interests.

\section{FUNDING}

This work was partially supported by the National Natural Scientific Foundation (No. 81473471).

\section{REFERENCES}

1. Jabre P, Roger VL, Murad MH, Chamberlain AM, Prokop L, Adnet F, Jouven X. Mortality associated with atrial fibrillation in patients with myocardial infarction: a systematic review and meta-analysis. Circulation. 2011; 123:1587-1593.

2. Nattel S. New ideas about atrial fibrillation 50 years on. Nature. 2002; 415:219-226.

3. Pai SM, Pai RG. Management of atrial fibrillation. N Engl J Med. 1992; 327:1031.

4. Jabre P, Jouven X, Adnet F, Thabut G, Bielinski SJ, Weston SA, Roger VL. Atrial fibrillation and death after myocardial infarction: a community study. Circulation. 2011; 123:2094-2100

5. Rathore SS, Berger AK, Weinfurt KP, Schulman KA, Oetgen WJ, Gersh BJ, Solomon AJ. Acute myocardial infarction complicated by atrial fibrillation in the elderly: prevalence and outcomes. Circulation. 2000; 101:969-974.

6. Asanin M, Perunicic J, Mrdovic I, Matic M, Vujisic-Tesic B, Arandjelovic A, Vasiljevic Z, Ostojic M. Prognostic significance of new atrial fibrillation and its relation to heart failure following acute myocardial infarction. Eur J Heart Fail. 2005; 7:671-676.

7. Schmitt J, Duray G, Gersh BJ, Hohnloser SH. Atrial fibrillation in acute myocardial infarction: a systematic review of the incidence, clinical features and prognostic implications. Eur Heart J. 2009; 30:1038-1045.

8. Stroup DF, Berlin JA, Morton SC, Olkin I, Williamson GD, Rennie D, Moher D, Becker BJ, Sipe TA, Thacker SB. Meta-analysis of observational studies in epidemiology: a proposal for reporting. Meta-analysis Of Observational Studies in Epidemiology (MOOSE) group. JAMA. 2000; 283:2008-2012.

9. Higgins JP, Thompson SG. Quantifying heterogeneity in a meta-analysis. Stat Med. 2002; 21:1539-1558.
10. Aronson D, Boulos M, Suleiman A, Bidoosi S, Agmon Y, Kapeliovich M, Beyar R, Markiewicz W, Hammerman H, Suleiman M. Relation of C-reactive protein and newonset atrial fibrillation in patients with acute myocardial infarction. Am J Cardiol. 2007; 100:753-757.

11. Hwang HJ, Ha JW, Joung B, Choi EH, Kim J, Ahn MS, Lee MH, Jang Y, Chung N, Kim SS. Relation of inflammation and left atrial remodeling in atrial fibrillation occurring in early phase of acute myocardial infarction. Int J Cardiol. 2011; 146:28-31.

12. Gedikli O, Orem C, Baykan M, Karahan C, Kucukosmanoglu M, Sahin S, Korkmaz L, Yilmaz H, Celik S. Association between serum $\mathrm{C}$-reactive protein elevation and atrial fibrillation after first anterior myocardial infarction. Clin Cardiol. 2008; 31:482-487.

13. Guenancia C, Stamboul K, Garnier F, Beer JC, Touzery C, Lorgis L, Cottin Y, Zeller M. Obesity and new-onset atrial fibrillation in acute myocardial infarction: a gender specific risk factor. Int J Cardiol. 2014; 176:1039-1041.

14. Yoshizaki T, Umetani K, Ino Y, Takahashi S, Nakamura M, Seto T, Aizawa K. Activated inflammation is related to the incidence of atrial fibrillation in patients with acute myocardial infarction. Intern Med. 2012; 51:1467-1471.

15. Dorje T, Wang X, Shao M, Zhou J, Cui X, Zhang F, Qian J, Ge J. Plasma N-terminal pro-brain natriuretic peptide levels predict new-onset atrial fibrillation in patients with acute myocardial infarction. Int J Cardiol. 2013; 168:3135-3137.

16. Zhang X, Li G, Zhao Z, Xu Y, Liu T. The value of CHADS2 score in predicting new-onset atrial fibrillation in Chinese patients with acute myocardial infarction. Int $\mathrm{J}$ Cardiol. 2014; 176:1235-1237.

17. Cicek D, Camsari A, Pekdemir H, Kiykim A, Akkus N, Sezer K, Diker E. Predictive value of P-wave signal-averaged electrocardiogram for atrial fibrillation in acute myocardial infarction. Ann Noninvasive Electrocardiol. 2003; 8:233-237.

18. Bahouth F, Mutlak D, Furman M, Musallam A, Hammerman H, Lessick J, Dabbah S, Reisner S, Agmon Y, Aronson D. Relationship of functional mitral regurgitation to new-onset atrial fibrillation in acute myocardial infarction. Heart. 2010; 96:683-688.

19. Aronson D, Mutlak D, Bahouth F, Bishara R, Hammerman H, Lessick J, Carasso S, Dabbah S, Reisner $\mathrm{S}$, Agmon Y. Restrictive left ventricular filling pattern and risk of new-onset atrial fibrillation after acute myocardial infarction. Am J Cardiol. 2011; 107:1738-1743.

20. Liu T, Li G, Li L, Korantzopoulos P. Association between C-reactive protein and recurrence of atrial fibrillation after successful electrical cardioversion: a meta-analysis. J Am Coll Cardiol. 2007; 49:1642-1648.

21. Lau DH, Alasady M, Brooks AG, Sanders P. New-onset atrial fibrillation and acute coronary syndrome. Expert Rev Cardiovasc Ther. 2010; 8:941-948.

22. Sakata K, Kurihara H, Iwamori K, Maki A, Yoshino $\mathrm{H}$, Yanagisawa A, Ishikawa K. Clinical and 
prognostic significance of atrial fibrillation in acute myocardial infarction. Am J Cardiol. 1997; 80:1522-1527.

23. Crenshaw BS, Ward SR, Granger CB, Stebbins AL, Topol EJ, Califf RM. Atrial fibrillation in the setting of acute myocardial infarction: the GUSTO-I experience. Global Utilization of Streptokinase and TPA for Occluded Coronary Arteries. J Am Coll Cardiol. 1997; 30:406-413.

24. Wong CK, White HD, Wilcox RG, Criger DA, Califf RM, Topol EJ, Ohman EM. New atrial fibrillation after acute myocardial infarction independently predicts death: the GUSTO-III experience. Am Heart J. 2000; 140:878-885.

25. Pizzetti F, Turazza FM, Franzosi MG, Barlera S, Ledda A, Maggioni AP, Santoro L, Tognoni G, GISSI-3 Investigators. Incidence and prognostic significance of atrial fibrillation in acute myocardial infarction: the GISSI-3 data. Heart. 2001; 86:527-532.

26. Schmiegelow MD, Pedersen OD, Kober L, Seibaek M, Abildstrom SZ, Torp-Pedersen C. Incidence of atrial fibrillation in patients with either heart failure or acute myocardial infarction and left ventricular dysfunction: a cohort study. BMC Cardiovasc Disord. 2011; 11:19.

27. Ren Y, Zeng RX, Li JJ, Guo LH, He DY, Li Y, Liao PD, Zhang MZ. Relation of C-reactive protein and newonset atrial fibrillation in patients with acute myocardial infarction: A systematic review and meta-analysis. Int J Cardiol. 2015; 190:268-270.

28. Gao X, Zeng R, Liao P, Zhu H, Zhang M. Relation of $\mathrm{N}$-terminal pro-brain natriuretic peptide and new-onset atrial fibrillation in patients with acute coronary syndrome: a systematic review and meta-analysis. Scand J Clin Lab Invest. 2016; 76:460-464.

29. Eldar M, Canetti M, Rotstein Z, Boyko V, Gottlieb S, Kaplinsky E, Behar S. Significance of paroxysmal atrial fibrillation complicating acute myocardial infarction in the thrombolytic era. SPRINT and Thrombolytic Survey Groups. Circulation. 1998; 97:965-970.

30. Pedersen OD, Abildstrom SZ, Ottesen MM, Rask-Madsen C, Bagger H, Kober L, Torp-Pedersen C, TRACE Study Investigators. Increased risk of sudden and non-sudden cardiovascular death in patients with atrial fibrillation/flutter following acute myocardial infarction. Eur Heart J. 2006; 27:290-295.

31. Goldberg RJ, Seeley D, Becker RC, Brady P, Chen ZY, Osganian V, Gore JM, Alpert JS, Dalen JE. Impact of atrial fibrillation on the in-hospital and long-term survival of patients with acute myocardial infarction: a communitywide perspective. Am Heart J. 1990; 119:996-1001.

32. Hod H, Lew AS, Keltai M, Cercek B, Geft IL, Shah PK, Ganz W. Early atrial fibrillation during evolving myocardial infarction: a consequence of impaired left atrial perfusion. Circulation. 1987; 75:146-150.
33. Ravelli F, Allessie M. Effects of atrial dilatation on refractory period and vulnerability to atrial fibrillation in the isolated Langendorff-perfused rabbit heart. Circulation. 1997; 96:1686-1695.

34. Grigioni F, Avierinos JF, Ling LH, Scott CG, Bailey KR, Tajik AJ, Frye RL, Enriquez-Sarano M. Atrial fibrillation complicating the course of degenerative mitral regurgitation: determinants and long-term outcome. J Am Coll Cardiol. 2002; 40:84-92.

35. Tani T, Tanabe K, Ono M, Yamaguchi K, Okada M, Sumida T, Konda T, Fujii Y, Kawai J, Yagi T, Sato M, Ibuki M, Katayama M, et al. Left atrial volume and the risk of paroxysmal atrial fibrillation in patients with hypertrophic cardiomyopathy. J Am Soc Echocardiogr. 2004; 17:644-648.

36. Ariyarajah V, Malinski M, Khadem A, Harizi R, Wolfe K, Spodick DH. Relation of recurrence of atrial fibrillation after non-ST-elevation acute myocardial infarction to left atrial abnormality. Am J Cardiol. 2008; 101:30-34.

37. Lip GY, Windecker S, Huber K, Kirchhof P, Marin F, Ten Berg JM, Haeusler KG, Boriani G, Capodanno D, Gilard M, Zeymer U, Lane D, Document R, et al. Management of antithrombotic therapy in atrial fibrillation patients presenting with acute coronary syndrome and/or undergoing percutaneous coronary or valve interventions: a joint consensus document of the European Society of Cardiology Working Group on Thrombosis, European Heart Rhythm Association (EHRA), European Association of Percutaneous Cardiovascular Interventions (EAPCI) and European Association of Acute Cardiac Care (ACCA) endorsed by the Heart Rhythm Society (HRS) and AsiaPacific Heart Rhythm Society (APHRS). Eur Heart J. 2014; 35:3155-3179.

38. Kirchhof P, Benussi S, Kotecha D, Ahlsson A, Atar D, Casadei B, Castella M, Diener HC, Heidbuchel H, Hendriks J, Hindricks G, Manolis AS, Oldgren J, et al. 2016 ESC Guidelines for the management of atrial fibrillation developed in collaboration with EACTS. Europace. 2016; 18:1609-1678.

39. Gorenek B, Pelliccia A, Benjamin EJ, Boriani G, Crijns HJ, Fogel RI, Van Gelder IC, Halle M, Kudaiberdieva G, Lane DA, Larsen TB, Lip GY, Lochen ML, et al. European Heart Rhythm Association (EHRA)/European Association of Cardiovascular Prevention and Rehabilitation (EACPR) position paper on how to prevent atrial fibrillation endorsed by the Heart Rhythm Society (HRS) and Asia Pacific Heart Rhythm Society (APHRS). Europace. 2017; 19:190-225. 